\title{
IMPLEMENTASI TOTAL QUALITY MANAGEMENT DALAM SISTEM MANAJEMEN MUTU PEMBELAJARAN DI INSTITUSI PENDIDIKAN
}

\author{
Achmad Supriyanto \\ FIP Universitas Negeri Malang (e-mail: aspriess@gmail.com; HP. 081334096498)
}

\begin{abstract}
Implementation of the Total Quality Management in the Learning Quality Management System in Educational Institutions. This study aimed to analyse the implementation of the Total Quality Management (TQM) in the learning quality management system in educational institutions. This study used a descriptive design. The population consisted of people in the organizational structure of the quality management system and the sample was pusposively selected. The data were collected through interviews and documents and were analysed using the descriptive technique. The findings show that: (1) the TQM has been implemented but it still needs optimizing, (2) it needs support from the heads of relevant units, (3) there are constraints because of work teams that are not optimal and limited time and funds, (4) the strategies to deal with the constraints depend on the condition and situation, and (5) the implementation of the TQM refers to an evaluation and monitoring study and the draft of academic quality assurance documents.
\end{abstract}

Keywords: implementation, TQM, learning, education

\section{PENDAHULUAN}

Berbagai upaya untuk meningkatkan kualitas pendidikan tinggi telah, sedang, dan akan terus dilaksanakan secara bertahap dan berkelanjutan. Strategi pengembangannya antara lain dilakukan dengan menerapkan paradigma baru berupa peningkatan kualitas berkelanjutan di masa mendatang yang dikenal dengan nama Total Quality Management (TQM). Prinsipprinsip dasar yang terkandung di dalamnya telah diadopsi oleh perguruan tinggi. Pelaksanaan program TQM dapat menggunakan nama yang disepakati oleh pihak-pihak yang berkepentingan. Beberapa organisasi memakai filosofi dengan nama sendiri. Apa pun namanya dapat digunakan, misalnya, Total Quality Control, Total Quality service, Continuos Improvement, strategic Quality Initiatives, Service Quality (Sallis, 1993:75) ataupun Sistem Manajemen Mutu (Gandem, 1999:14). Melalui penamaan tersebut, diharapkan berpengaruh terhadap budaya kualitas di dalam organisasi yang bersangkutan.

TQM berkaitan dengan penciptaan budaya kualitas yang bertujuan agar karyawan dan staf dapat memuaskan konsumen sekaligus didukung oleh struktur organisasi mereka dalam melakukan hal yang dimaksud 
(Ramdass \& Kruger, 2006:9). TQM dianggap sebagai suatu pendekatan dalam menjalankan usaha yang mencoba untuk memaksimalkan daya saing organisasi melalui perbaikan terusmenerus atas produk, jasa, manusia, proses dan lingkungannya (Tjiptono dan Diana, 2000:4). Organisasi yang menggunakan TQM berupaya untuk mengadakan perbaikan secara berkelanjutan dalam rangka memenangkan persaingan dalam era global mendatang. Upaya yang dimaksudkan berupalangkah-langkah untuk meningkatkan perbaikan berkelanjutan, seperti (1) customer focus; (2) improvement process; dan (3) total involvement (Tenner dan DeToro, 2000:32). Esensi TQM adalah suatu filosofi yang menunjuk pada perubahan budaya dalam suatu organisasi, serta dapat menyentuh hati dan pikiran orang menuju mutu yang diidamkan.

Beberapa indikasi keberhasilan organisasi yang mengimplementasikan TQM ditunjukkan melalui: (1) komitmen yang tinggi dari seluruh jajaran organisasi (pimpinan tertinggi sampai dengan karyawan terendah); (2) organisasi yang mantap; dan (3) motivasi dan disiplin yang tinggi (Gandem, 1999:14). Keberhasilan TQM juga sangat ditentukan oleh lima pilar penyangganya, yaitu: (1) produk; (2) proses, (3) organisasi, (4) kepemimpinan; dan (5) komitmen (Creech, 2000:447).

Memang tidak sepenuhnya TQM berhasil diimplementasikan pada organisasi karena berbagai faktor penyebab. Tjiptono dan Diana (2000: 4) menyatakan bahwa faktor yang me- nyebabkan kegagalan dalam mengimplementasikan TQM, antara lain: (1) perubahan yang menyeluruh (paradigma manajemen, komitmen, tujuan, dan pelatihan) tidak dipenuhi; (2) usaha setengah hati dan harapan tidak realistis; dan (3) kesalahan delegasi dan kepemimpinan, tim, proses penyebarluasan, pendekatan terbatas, dan pemberdayaan yang prematur. Kendala lain yang dihadapi oleh organisasi antara lain penciptaan lingkungan yang mendukung usaha perbaikan dan berorientasi pada mutu masih kurang, pemahaman terhadap perencanaan strategis dan dialogis masih kurang, pemberdayaan sumber daya manusia masih kurang, komitmen dan partisipasi karyawan program perbaikan mutu masih kurang, dan sistem informasi manajemen pendukung pelaksanaan program peningkatan mutu kurang mendapat perhatian.

Implementasi TQM pada SMM pembelajaran dapat diadopsi dari Tenner \& DeToro (2000:32). Model tersebut mengandung tiga hal utama, yaitu tujuan, prinsip, dan elemenelemen TQM. Tujuan utama TQM dalam pendidikan adalah meningkatkan mutu pendidikan secara berkelanjutan, terus-menerus, dan terpadu. Pencapaian tujuan dapat diwujudkan menggunakan prinsip-prinsip pemfokusan pada pengguna, peningkatan kualitas pada proses, dan pelibatan semua komponen pendidikan. Beberapa elemen pendukung untuk mencapai tujuan peningkatan kualitas pendidikan secara berkelanjutan, yaitu kepemimpinan, pendidikan dan 
pelatihan, struktur pendukung, komunikasi, penghargaan, pengukuran.

Ada beberapa faktor pendukung dan penghambat dalam implementasi TQM ke dalam SMM di institusi pendidikan di perguruan tinggi. Beberapa pakar di bidang ini telah menyumbangkan hasil kajian maupun penelitiannya. Hasil penelitian Change Management Learning Centeratau CMLC (2004:47) telah menemukan lima besar yang menjadi variabel pendukung perubahan dan penghambat kesuksesan (the top-five contributors to success and the top-five greatest CM obstacles). Ada lima faktor yang mendukung kesuksesan dalam perubahan organisasional, yaitu dukungan yang efektif, persatuan dan kesatuan dari barisan manajer dan para pegawai, tim khusus, perubahan terus-menerus dan komunikasi sesuai target, perencanaan yang baik dan pendekatan yang diorganisir.

Beberapa faktor penghambat perubahan organisasional penolakan dari pegawai dan staf, penolakan dari manajemen menengah, dan dukungan pelaksana yang buruk, waktu, anggaran biaya, sumber daya terbatas, dan kelembaman dan politik organisasi. CMLM (2004:49) menyatakan, bahwa "An organization's culture, history, values and capacity for change are potential obstacles for change management teams", ..."consultants and change management teams often address these potential barriers with assessments". Artinya, tidak saja dari sisi manusianya saja yang dapat menjadi rintangan dalam perubahan organisasional, tetapi ada rintangan potensial yang berasal dari budaya organisasi, sejarah, nilai dan kapasitas untuk perubahan. Penolakan terhadap perubahan organisasional sangat membutuhkan penanganan yang serius dari pihak-pihak yang berkompeten (agen perubahan). Ada beberapa strategi yang dapat dijadikan pedoman untuk mengatasinya.

\section{METODE}

Penelitian ini bertujuan untuk menganalisis implementasi TQM dalam SMM pembelajaran di institusi pendidikan. Penelitian ini mengambil kasus di BPM, GPM, dan UPM yang dilaksanakan di FIP UM. Penelitian ini tidak memberikan treatment (perlakuan), tetapi berdasarkan tujuannya untuk mengungkap data yang ada sehingga penelitian ini menggunakan rancangan penelitian deskriptif.

Variabel penelitian ini adalah implementasi TQM dalam SMM. Implementasinya menunjuk pada suatu upaya penerapan konsep TQM ke dalam suatu Sistem Manajemen Mutu (SMM) di institusi pendidikan. Variabel, sub variabel, dan indikator penelitian ini dapat dilihat pada Tabel 1. 
Tabel 1. Variabel, Sub-Variabel, dan Indikator Penelitian

\begin{tabular}{lll}
\hline \multicolumn{1}{c}{ Variabel } & \multicolumn{1}{c}{ Sub Variabel } & \multicolumn{1}{c}{ Indikator } \\
\hline Implementasi & Keberhasilan & Rumusan Tujuan SMM \\
TQM dalam & implementasi TQM dalam & Prinsip-prinsip TQM dalam pelaksanaan \\
& SMM & SMM \\
& & Komponen TQM dalam SMM \\
& Pendukung implementasi & Pimpinan \\
& TQM dalam SMM & Pelaksana \\
& & Tim Khusus (BPM, GPM, dan UPM) \\
& Penghambat & Sumber daya manusia (pimpinan, \\
& implementasi TQM dalam & pelaksana, tim khusus) \\
& SMM & Waktu \\
& & Anggaran \\
& Sumber daya lain (sarana \& prasarana) \\
& Strategi BPM, GPM, dan & Pendidikan \& komunikasi \\
UPM dalam mengatasi & Partisipasi \\
berbagai hambatan & Fasilitas \& dukungan \\
& Negosiasi \\
& Manipulassi \& kooptasi \\
& Pemaksaan \\
& \\
Hasil-hasil implementasi & Dokumen Pembelajaran \\
& Non Dokumen Pembelajaran \\
\hline &
\end{tabular}

Populasi dalam penelitian ini adalah orang yang masuk dalam struktur organisasi BPM (UM), GPM, dan UPM yang ada di FIP UM. Jumlah populasi dua puluh delapan (28) orang. Dengan memperhatikan situasi dan kondisi populasi yang ada (kesibukan, waktu, dan keakuratan sumber informasi, dan informan), pada akhirnya sampel diambil secara purposive. Pengambilan sampel tersebut didasarkan pada kesediaan responden, keakuratan data yang diberikan, dan representasi masing-masing unit yang berjumlah enam (6) UPM. Jumlah responden sebanyak dua belas (12) orang.
Data penelitian ini dikumpulkan dengan teknik-teknik wawancara dan studi dokumenter. Teknik analisis deskriptif kualitatif digunakan untuk mengungkap gambaran keberhasilan implementasi konsep TQM pada SMM dalam pembelajaran. Langkah-langkah analisis meliputi pengumpulan data, reduksi data, analisis kecenderungan untuk menghasilkan kategori, dan penarikan kesimpulan.

\section{HASIL}

Hasil-hasil penelitian ini dapat dideskripsikan berdasarkan urutan pencapaian tujuan penelitian. Berdasarkan tujuan yang sudah ditentukan, 
ada lima (5) aspek yang diungkap dalam penelitian ini. Pertama, tingkat keberhasilan implementasi TQM pada SMM pembelajaran dapat ditinjau dari tiga aspek, yaitu: (1) perumusan tujuan peningkatan mutu; (2) penerapan prinsip-prinsip TQM pada SMM; dan (3) komponen pendukung implementasi TQM pada SMM. Hasil analisis data ditunjukkan sebagai berikut. Rumusan tujuan SMM pembelajaran untuk peningkatan mutu di masing-masing jurusan sudah tersedia, dianggap sudah cukup jelas, dan dilakukan perbaikan ketika ditemukan sesuatu yang belum sesuai. Rumusan tujuan SMM tersebut sudah ada dan sedikit mengalami perbaikan.

Penerapan prinsip-prinsip TQM pada SMM yang mencakup pemfokusan pada pelanggan, perbaikan pada proses, dan pelibatan anggota dalam berbagai kegiatan SMM. Pemfokusankegiatan ke pelanggan (mahasiswa, dosen, dan staf) sudah dilakukan, tetapi belum optimal. Kondisi yang ada menunjukkan adanya perubahan pelayanan terhadap mahasiswa sebelum dan sesudah BPM, UPM, dan GPM. Perbaikan proses kegiatan secara terus-menerus, khususnya terkait dengan proses pembelajaran sudah tampak dari meningkatnya kedisiplinan dan komitmen dosen dalam melaksanakan proses perkuliahan (kehadiran dosen, penyusunan RPS, penyelenggaraan evaluasi pembelajaran, presensi kehadiran mahasiswa, sampai pada pengembalian tugas dan hasil ujian mahasiswa). Hal tersebut terkontrol melalui Monev yang dilakukan GPM, UPM, dan
BPM. Kegiatan ini dilakukan tiga kali dalam satu semester. Pelibatan anggota organisasi oleh BPM secara menyeluruh belum dilakukan secara optimal. Hal ini ditunjukkan oleh anggota organisasi yang belum sepenuhnya terlibat dalam kegiatan penjaminan mutu.

Komponen pendukung implementasi TQM pada SMM dalam penelitian ini mencakup aspek, yaitu (1) kepemimpinan; (2) diklat; (3) komunikasi; (4) pengukuran; (5) dukungan struktur; dan (6) penghargaan. Komponen kepemimpinan pada masing-masing jurusan, dan fakultas sebagai pendukung implementasi TQM pada SMM pembelajaran dinilai cukup. Pelaksanaan diklat belum dapat dikatakan baik. Hal ini karena pelaksanaan diklat belum dapat diimplementasikan secara optimal, bahkan ada yang menyatakan pelaksanaan diklat dinilai tidak baik. Komunikasi yang dibangun pada SMM dinilai cukup baik, terutama tampak pada kegiatan sosialisasi standar dan tujuan BPM, UPM, dan GPM sebagai sebuah unit independen yang membantu proses perbaikan kinerja seluruh unit dan komponen yang ada, khususnya berkaitan dengan pelaksanaan kegiatan akademik. Hal yang menunjukkan belum optimal terjadi pada sosialisasi hasil dan upaya tindak lanjut masingmasing GPM yang sudah disampaikan kepada BPM. Pengukuran kinerja sudah dilakukan setiap unit, terutama pada UPM dan masing-masing GPM berdasarkan standar yang telah ditetapkan oleh BPM. Masing-masing unit menetapkan standar mengacu 
pada standar yang sudah ada. Struktur sebagai konfigurasi formal komunikasi antara BPM, UPM, dan GPM dinilai sangat baik. Keberadaan BPM, UPM, dan GPM sebagai unit atau badan independen yang bertugas memberikan rekomendasi dan masukan terkait dengan pelaksanaan akademik melalui kegiatan monev untuk diberikan kepada pejabat struktural yang memiliki wewenang untuk melakukan upaya tindak lanjut berdasarkan temuan tersebut. Dukungan struktur terlihat dalam menyediakan bahan-bahan yang diperlukan untuk menyusun laporan GPM serta menyediakan waktu dan dana dalam mensosialisasikan hasil kerja GPM. Penghargaan khusus terhadap keterlaksanaan kinerja GPM dan UPM ataupun kinerja unit dan komponen belum memberkan dampak yang signifikan bagi peningkatan kinerja masing-masing unit.

Kedua, dukungan pihak pimpinan, pelaksana, tim khusus, dalam implementasi TQM pada SMM pembelajaran sangat diperlukan untuk mencapai keberhasilan mutu yang diharapkan. Berdasarkan analisis data diperoleh hasil bahwa dukungan pimpinan unit kerja dinilai baik oleh anggota dalam upaya tidak lanjut, satgas pelaksana cukup mendukung kegiatan penjaminan mutu, dan kekompakkan tim cukup mendukung kegiatan penjaminan mutu. Kondisi ini sangat positif agar keberlangsungan UPM dan GPM di institusi pendidikan untuk mendukung kinerja BPM secara keseluruhan.

Ketiga, ada beberapa hambatan yang berasal dari sumber daya ma- nusia, waktu, dan sumber daya lainnya yang diperlukan. Gambaran hambatan dari aspek sumber daya manusia, waktu, anggaran, dan sumber daya lain (sarana dan prasarana) yang diperlukan dalam implementasi TQM pada SMM melalui BPM, GPM, dan UPM yang dilaksanakan dapat diketahui. Hampir semua pimpinan bukan menjadi hambatan, tetapi mendukung aktivitas implementasi TQM pada SMM pembelajaran. Kinerja satuan tugas cukup bagus, hanya ada beberapa hal yang perlu mendapat perhatian khusus, seperti ada beberapa anggota GPM yang mengatakan bahwa: (1) kekompakkan tim menjadi hambatan; (2) waktu merupakan kendala paling besar dalam pelaksanaaan kegiatan penjaminan mutu, baik dari pimpinan unit kerja, satgas, dan para dosen; dan (3) biaya untuk pelaksanaan kegiatan penjaminan mutu disediakan di institusi pendidikan walaupun dana terbatas.

Keempat, strategi BPM, GPM, dan UPMdalam mengatasi berbagai hambatan dalam implementasi TQM pada SMMpembelajaran ditinjau dari strategi yang dikembangkan dari perspektif manajemen perubahan. Strategi yang dimaksudkan meliputi: pendidikan dan komunikasi, partisipasi, fasilitas dan dukungan, negosiasi, manipulasi dan kooptasi, dan pemaksaan. Penggunaan strategistrategi tersebut dalam implementasi TQM pada SMM dapat dilihat sebagai berikut. Diklat dan komunikasi tidak secara intensif dilaksanakan sebagai strategi BPM, UPM dan GPM dalam mengatasi berbagai hambatan 
yang ada. Pelibatan anggota merupakan strategi yang selalu digunakan untuk mengatasi hambatan dalam kegiatan penjaminan mutu. Penyediaan fasilitas dan pemberian dukungan diberikan oleh pimpinan unit, namun hal tersebut pada kondisi tertentu tidak dapat diberikan. Dalam pelaksanaan kegiatan penjaminan mutu, strategi negosiasi terkadang dilakukan. Praktik manipulasi dan kooptasi ada, terutama terkait dengan pencapaian standar pada masing-masing GPM. Pemaksaan tidak pernah dilakukan, baik oleh pimpinan unit maupun pelaksana penjaminan mutu.

Seluruh komponen bekerja berdasarkan ketentuan dengan segenap kesadaran masing-masing pihak sesuai dengan tugas yang dipercayakan secara sinergis. Fokus utama dari kegiatan penjaminan mutu, baik mulai dari tingkat GPM, UPM, sampai dengan BPM adalah menanamkan budaya mutu pada setiap unit kerja berikut seluruh komponennnya. Budaya mutu yang dibangun akan mendukung keberhasilan institusi tersebut mencapai tujuan yang telah ditetapkan.

Kelima, hasil-hasil implementasi TQM pada SMM pembelajaran menunjuk pada dua (2) hasil utama, yaitu monitoring dan evaluasi (monev) pembelajaran dan draft naskah dokumen penjaminan mutu akademik. Hasil monev pembelajaran pada jurusanjurusan diketahui bahwa UPM dan GPM sebagian besar sudah melaksanakan monev pembelajaran tetapi ada sebagian kecil belum melaporkan.
Sasaran utama monev pembelajaran mencakup tiga hal, yaitu: kehadiran dosen, kehadiran mahasiswa, dan Rencana Perkuliahan Semester (RPS). Rata-rata kehadiran dosen mencapai $54,30 \%$, tingkatkehadiran mahasiswa mencapai $53,45 \%$, dan penyampaian RPS dosen ke mahasiswa mencapai 39, 27\%. Pencapaian-pencapaian tersebut (kehadiran dosen dan mahasiswa) belum maksimal karena ada jurusan yang belum menyerahkan laporan ke UPM. Pencapaian RPS dari dosen ke mahasiswa juga masih $39,27 \%$ karena jurusan belum menyerahkan ke pihak UPM (dosen ada tugas lain ketika monev berlangsung).

Draft naskah dokumen penjaminan mutu akademik yang dihasilkan terdiri dari: (1) kebijakan akademik fakultas; (2) standar akademik fakultas; (3) manual mutu sistem penjaminan mutu akademik; dan (4) standar operasional prosedur audit mutu akademik. Namun demikian, draft naskah tersebut sampai dengan penelitian ini dilakukan belum disahkan oleh senat fakultas.

\section{PEMBAHASAN}

Implementasi TQM pada SMM di institusi pendidikan sudah dijalankan, tetapi belum optimal. Hal ini didukung oleh adanya penciptaan budaya kualitas pada sistem pembelajaran. Namun demikian, penciptaan budaya kualitas pembelajaran tersebut membutuhkan proses yang panjang, perlu dilakukan secara bertahap dan kerkelanjutan, serta membutuhkan sumber daya manusia dan nonmanusia yang yang memadai. 
Penerapan prinsip-prinsip TQM pada SMM yang mencakup pemfokusan pada pelanggan, perbaikan pada proses, dan pelibatan anggota dalam berbagai kegiatan telah berjalan. Pemfokusan kegiatan pada pelanggan (mahasiswa, dosen, dan staf) sudah dilakukan, tetapi belum optimal. Jika prinsip-prinsip tersebut dilakukan secara konsisten dalam jangka panjang, dapat menghasilkan layanan jasa pendidikan yang baik. Hal ini sesuai dengan prinsip yang harus diperhatikan, yaitu selalu ada perbaikan dalam setiap proses ketika mengimplementasikan TQM padainstitusi pendidikan tinggi (Ramdass \& Kruger, 2006). Terdapat perbedaan dengan apa yang pernah dilakukan dalampenerapanprinsip-prinsip TQM di The Higher Hotel Institute, Cyprus. Penerapannya masih menjadi tantangan yang besar karena tidak ada prinsip khusus, tetapi wujudnya dapat diamati secara jelas. Tidak ada pendekatan formal, lembaga ini hanya menerapkan apa yang ada di literatur, terutama dalam membangun dasar yang kuat melalui budaya manajemen yang menekankan pada pelanggan (Varnavas \& Soteriou, 2002).

Adanya dukungan pimpinan unit kerja dinilai baik oleh anggota dalam upaya tidak lanjut, satgas pelaksana cukup mendukung kegiatan penjaminan mutu, dan kekompokkan tim cukup mendukung kegiatan penjaminan mutu. Kondisi ini sangat positif untuk keberlangsungan UPM dan GPM di institusi pendidikan guna mendukung kinerja BPM secara keseluruhan. Hasilpenelitian ini memper- kuat penelitian Change Management Learning Center (CMLC) pada tahun 2004 yang telah menemukan lima besar yang menjadi variabel pendukung atau kontributor (the top-five contributors to success) pada perubahan dan penghambat kesuksesan perubahan (the top-five greatest CM obstacles).

Variabel pendukung keterlaksanaan program BPM, UPM, dan GPM mengacu pada the top-five contributors to success yaitu: adanya dukungan yang efektif (effective sponsorship), yaitu dukungan dari rektor UM yang memberikan keleluasaan kepada BPM untuk menjalankan tiga pokok dan fungsinya dengan SK Rektor Nomor 0033a/KEP /36/HK/2006. Hal ini ditindaklanjuti dengan dukungan dari struktur pada masing-masing UPM dan GPM. Ada persatuan dan kesatuan dari barisan manajer dan para pegawai meskipun tidak secara menyeluruh. Tim khusus BPM, UPM, dan GPM melalui Satgas yang dibentuk juga memberikan kontribusi terhadap keterlaksanaan program penjaminan mutu. Seluruh jajaran BPM, UPM, dan GPM berupaya melakukan continous improvement pada setiap unit kerja, namun hal tersebut tidak didukung dengan komunikasi sesuai dengan target yang ditentukan. Artinya, hasil dari perbaikan tidak dikomunikasikan kepada unit kerja sebagai feed back dari kegiatan yang telah dilaksanakan. Komunikasi belum dilakukan secara konsisten, terbuka, memenuhi sasaran pada sasaran yang tepat dan dilakukan dengan alat bantu yang bervariasi. Perencanaan yang disusun oleh jajaran penjaminan 
mutu UM cukup komprehensif di BPM, namun perencanaan belum dilakukan pada masing-masing GPM. Pendekatan yang dilakukan juga belum terorganisir dengan baik. Hal ini ditunjukkan dengan adanya keterlambatan pelaporan dari masing-masing UPM dan GPM sehingga feedback tidak dapat diberikan segera dan hal ini menjadi hambatan untuk menyusun kegiatan dalam rangka melakukan continous improvement. Hasil ini melengkapi penelitian Taylor \& Hill (1992:1) bahwa faktor penentu kesuksesan TQM ada pada struktur, kultur , manajemen sumber daya manusia, dan kepemimpinan organisasional.

Memang ditemukan ada beberapa hambatan dalam mengimplementasikan TQM pada SMM, terutama berasal dari sumber daya manusia, wak$\mathrm{tu}$, dan sumber daya lainnya yang diperlukan. Hambatan-hambatan tersebut tidak berbeda dengan yang sudah diteliti oleh CMLC (2004) yang disebutnya sebagai the top-five greatest CM obstacles. Kelimanya meliputi penolakan dari pegawai dan staf, penolakan dari manajemen menengah, dan dukungan pelaksana yang buruk, waktu, anggaran biaya, dan sumber daya terbatas, serta kelembaman dan politik organisasi. Kesulitan lainnya adalah dalam mengkreasi implementtasi TQM di pendidikan tinggi karena berkaitan dengan isu kepemimpinan, budaya, dan isu-isu organisasional (Sirvanci, 2004:382). Beberapa perguruan tinggi jugamengalami kesulitan ketikamengimplementasikan TQM yang disebabkan oleh sistem periodisasi waktu yang kuat (Helms, Williams, dan Nixon, 2001:1). Berbagai kendala yang dihadapi perguruan tinggi ketika mengimplementasikan TQM cukup variatif sesuai dengan situasi dan kondisi institusi masing-masing. Semua itu membutuhkan strategi untuk mengatasinya sehingga walaupun ada kendala, TQM nantinya dapat diimplementasikan di bidang pendidikan dengan baik. Hal yang sangat disarankan untuk membangun institusi pendidikan yang baik adalah dengan cara meningkatkan kualitas pendidikan secara terus-menerus, terutama pada pembelajarannya agar para mahasiswa menjadi pemikir yang kritis dan kreatif dalam menghadapi perubahan teknologi yang cepat (Crawford dan Shutler, 1999).

Beberapa strategi BPM, GPM, dan UPM untuk mengatasi berbagai hambatan dalam implementasi TQM pada SMM pembelajaran dilakukan dengan cara membangun kesadaran masingmasing pihak sesuai dengan tugas yang dipercayakan kepada anggota unit tersebut secara sinergis. Penanaman budaya mutu pada setiap unit kerja berikut seluruh komponennnya juga selalu ditekankan dalam mendukung keberhasilan institusi tersebut mencapai tujuan yang telah ditetapkan. Sebenarnya, ada strategi sistematis yang dapat dijadikan acuan dalam mengatasi berbagai hambatan tersebut, yaitu mulailah dari strategi yang halus (pendidikan dan komunikasi) sampai dengan pemaksaan, serta strategi air. Ketika menghadapi penolakan yang kuat tidak selamanya harus dihadapi dengan strategi pemaksaan, tetapi diperlukan strategi yang dapat 
mendinginkan para penolaknya secara persuasif dan akhirnya mereka berubah menjadi pendukung implementasi TQM. Beberapa strategi yang telah dikemukakan para pakar, yaitu Kotler \& Schlesinger (1979), Robbins (2000), Robbins \& Coulter (2000) antara lain melalui pendidikan dan komunikasi, partisipasi dan penyertaan, pemberian fasilitas dan dukungan, negosiasi dan persetujuan, manipulasi dan pemilihaaan menjadi anggota, memaksa secara terang-terangan dan terselubung, serta strategi air. Semua strategi tersebut dapat dipilih dan dipilah untuk digunakan ketika menghadapi berbagai hambatan dalam implementasi TQM pada SMM di masa mendatang.

Hasil-hasil implementasi TQM dalam SMM pembelajaran menunjuk pada dua hasil utama, yaitu monitoring dan evaluasi (monev) pembelajaran dan draft naskah dokumen penjaminan mutu akademik. Hasil monev pembelajaran pada jurusanjurusan diketahui bahwa UPM dan GPM sebagian besar sudah melaksanakan monev pembelajaran, tetapi ada sebagian kecil belum melaporkan. Hasil tersebut tampak belum optimal karena pencapaiannya dilakukan secara bertahap dan berkesinambungan. Kondisi ini sangat wajar mengingat dalam penerapan hal-hal baru (TQM pada SMM pembelajaran) tidak serta merta secara langsung dapat menghasilkan yang maksimal.

Hasil penelitian terdahulu yang berkaitan dengan implementasi TQM di organisasi memang masih didominasi oleh kalangan dunia industri, sedangkandi bidang pendidikan (perguruan tinggi) masih relatif jarang. Pertama, hasil penelitian yang ada menunjukkan bahwa implementasi TQM di dunia bisnis sangat sukses (Supriyanto \& Rohmad, 2002:10). Hal ini dibuktikan oleh Perum Jasa Tirta (1999:15) yang sukses dalam mengembangkan dan menerapkan TQM. Perusahaan yang bergerak di bidang layanan jasa pengelolaan air dan melakukan pengembangan dan penerapan TQM dengan nama Sistem Jaminan Mutu ISO-9001. Hasil studi tersebut menunjukkan bahwa perusahaan ini mengimplementasikan TQM dengan nama Sistem Jaminan Mutu ISO-9001 (SJM ISO-9001).

Hal ini berbeda dengan implementasi TQM pada bidang pendidikan di perguruan tinggi berdasarkan data yang dikumpulkan oleh Quality Progress (QPR). Hasil penelitian ini menunjukkan bahwa pada tahun 1992 di Amerika Serikat sudah ada 220 institusi pendidikan tinggi yang menerapkan TQM (Lewis dan Smith dalam Tjiptono \& Diana, 2000:79). Harvard University, Oregon State University, University of Pennsylvania, University of Chicago, University of Texas-Austin adalah beberapa perguruan tinggi yang mengadopsi TQM. Perguruan tinggi tersebut menyatakan bahwa kehadiran TQM berdampak pada perubahan manajemen konvensional, termasukditemukan enam tantangan dalam menerapkannya, yaitu berkenaan dengan dimensi kualitas, fokus pada pelanggan, kepemimpinan, perbaikan berkesinambungan, manajemen SDM, dan manajemen berdasarkan fakta. 
Peningkatan kualitas pembelajaran dapat ditingkatkan apabila implementasi TQM dilakukan secara serius, didukung oleh stakeholders, berjalan secara sistemik dan sistematis, terusmenerus dan berkesinambungan.

\section{KESIMPULAN}

Pertama, keberhasilan implementasi TQM pada SMM pembelajaran dapat ditinjau dari tiga aspek, yaitu: (1) perumusan tujuan peningkatan mutu; (2) penerapan prinsip-prinsip TQM dalam SMM; dan (3) komponen pendukung implementasi TQM pada SMM. Rumusan tujuan tersedia, jelas, dan dilakukan perbaikan ketika ditemukan sesuatu yang belum sesuai dan mengalami perbaikan. Penerapan prinsip-prinsipnya mencakup pemfokusan pada pelanggan, perbaikan proses, dan pelibatan anggota dalam berbagai kegiatan. Komponen pendukung kepemimpinan dinilai cukup, diklat belum diimplementasikan secara optimal. Komunikasi cukup baik, pengukuran kinerja dilakukan setiap unit, struktur formal, dan komunikasi organisasi sangat baik. Dukungan struktur diperlukan dalam penyusunan laporan, penyediaan waktu dan dana dalam mensosialisasikan hasil kerja. Penghargaan atas kinerja anggota SMM pembelajaran belum memberikan dampak signifikan bagi peningkatan kinerjamasing-masingunit.

Kedua, dukungan pihak pimpinan dinilai baik oleh anggota dalam upaya tidak lanjut, satgas pelaksana cukup mendukung kegiatan penjaminan mutu, dan kekompokkan tim cukup mendukung kegiatan penja- minan mutu. Kondisi ini sangat positif untuk keberlangsungan SMM pembelajaran untuk mendukung kinerja secara keseluruhan.

Ketiga, hambatan dari aspek sumber daya manusia, waktu, anggaran, dan sumber daya dalam implementasi TQM dalam SMM pembelajaran yang dilaksanakan hampir semua pimpinan bukan menjadi hambatan, tetapi mendukung aktivitas implementasinya. Kinerja tim juga cukup bagus, hanya masih ada kendala, antara lain (1) kekompakkan tim; (2) waktu terbatas; dan (3) biaya terbatas.

Keempat, strategi yang digunakan untuk mengatasi berbagai hambatan dalam implementasi TQM pada SMM pembelajaran dilakukan melalui: (1) diklat dan komunikasi, tetapi tidak secara intensif dilaksanakan; (2) pelibatan anggota selalu digunakan; (3) penyediaan fasilitas dan pemberian dukungan diberikan oleh pimpinan unit, namun hal tersebut pada kondisi tertentu tidak dapat diberikan; (4) negosiasi kadang dilakukan; (5) praktik manipulasi dan kooptasi ada terutama terkait dengan pencapaian standar; dan (6) pemaksaaan tidak pernah dilakukan oleh pimpinan unit maupun pelaksana penjaminan mutu.

Kelima, hasil-hasil implementasi TQM pada SMM menunjuk pada dua (2) hal, yaitu: (1) monev pembelajaran; dan (2) draft naskah dokumen penjaminan mutu akademik di institusi pendidikan.

\section{SARAN}

Tim SMM pembelajaran perlu mempertahankan rumusan tujuan 
yang sudah ditetapkan, tetapi penerapan prinsip-prinsip TQM pada SMM perlu lebih diperhatikan dan dioptimalkan lagi dalam pelaksanaan program mendatang, termasuk di dalamnya harus memberdayakan pendukung-pendukungyang diperlukan dalamjangka panjang. Tim dalam mengatasi berbagai hambatan dalam implementasi TQM dalam SMM pembelajaran juga perlu lebih intensif dalam melaksanakan diklat, selalu melibatkan anggota secara keseluruhan, mengoptimalkan penggunaan fasilitas pendukung, sedangkan yang lainnya digunakan sesuai dengan situasi dan kondisi di lapangan.

Para pimpinan fakultas, jurusan, dan unit-unit yang terkait perlu tetap mendukung pelaksanaan implementasi TQM pada SMM pembelajaran dalam jangka panjang sehingga keberlangsungannya dapat tetap eksis. Namun demikian, karena masih adanya hambatan dari beberapa anggota GPM, terutama yang berkaitan dengan kekurangkompakkan tim, waktu yang terbatas (-kendala paling besar-), dan keterbatasan biaya, maka pimpinan fakultas perlu membuat solusi yang tepat, seperti membangun tim yang solid, mengalokasikan waktu khusus untuk melaksanakan program secara optimal. Hasil-hasil yang dicapai harus dijadikan dasar perbaikan, disosialisasikan kepada semua anggota organisasi nonsatgas, ditindaklajuti secara konsisten dan disinergikan untuk meningkatkan kualitas akademik dan non akademik .

Penelitian lanjutan dapat dilaksanakan oleh peneliti dengan mem- fokuskan pada implementasi TQM dalam SMM pembelajaran ditinjau dari variabel waktu yang lebih panjang, penerimaan anggota organisasi terhadap program-program jangka panjang, dan permasalahan-permasalahan yang paling sering timbul dan solusinya ketika melaksanakan program-program utama pada semua unit.

\section{UCAPAN TERIMA KASIH}

Terima kasih saya ucapkan kepada Dewan Redaksi Jurnal Cakrawala Pendidikan yang telah memberi saran yang berharga bagi perbaikan artikel ini. Terima kasih juga saya ucapkan kepada staf Jurnal Cakrawala Pendidikan Universitas Negeri Yogyakarta.

\section{DAFTAR PUSTAKA}
Al-Saket, A. 2003. A Case Study of Total quality Management in Manufac- turing and Construction Firm. Fa- culty of Enginerring at Rands Afrikaans University.

Change Management Learning Center. 2004. "ADKAR" -AModel for Change Management Change Management Tutorial Series. CMLC. Garfield Ave. Loveland, CO 80537 USA. http://www. Change Management.com.htm. Diakses tanggal 25 Pebruari 2007.

Crawford, L.E.D \& Shutler, P. 1999. “Total Quality Management In Education: Problems And Issues For The Classroom Teacher". International Journal of Educational Management, Vol. 13 Iss: 2. 
Creech, B. 2000. Lima Pilar (Manajemen Mutu Terpadu) TQM: Cara membuat Total Quality Management Bekerja bagi Anda. Jakarta: Binarupa Aksara.

Gandem, I.B. 1999. Penerapan Sistem Jaminan Mutu ISO-9001 di Perum Jasa Tirta. Makalah dalam Seminar dan Lokakarya tentang "Implementasi Konsep TQM untukMemaksimalkan Daya Saing Organisasi pada Era Globalisasi dan Perdagangan Bebas". Tanggal 8-10 Pebruari 1999. Malang: Universitas Brawijaya.

Helms, M.M., Williams, A.B., and Nixon, J.C. 2001. "TQM Principles And Their Relevance To Higher Education: The Question ff Tenure And Post-Tenure Review". International Journal of Educational Management, Vol. 15 Iss: 7.

Kotler, J.P. \& Schlesinger, LA. 1979. Choosing Strategies for Change. Harvard Business Review. 57 (2). Hal 106-114.

Nugraha, P. 2000. “Penerapan Manajemen Mutu Terpadu pada Matakuliah di Jurusan Teknik Sipil". Dimensi Teknik Sipil, Vol. 2, N0. 1, Maret 2000: 65-70.

Perum Jasa Tirta. 1999. Pedoman Mutu (Quality Manual). Malang: Perum Jasa Tirta.
Robbins, S.P., Coulter, M. 2000. Manajemen II. Jakarta: Prenhallindo.

Robbins, S. 2000. Perilaku Organisasi: Konsep, Kontroversi, Aplikasi. Edisi Kedua. Jakarta: Prenhallindo.

Ramdass, K. \& Kruger, D. 2006. Repositioning Quality Culture in Higher Education. Pretoria: University of Johannesburg.

Sirvanci, M.B. 2004. "Critical Issues for TQM Implementation in Higher Education". The TQM Magazine, Vol. 16 Iss: 6.

Taylor, A \& Hill, F.M. 1992. “Implementing TQM in Higher Education International". Journal of Educational Management. Volume: 6 Issue: 4.

Tenner, A. R., \& DeToro, I.J. 2000. Total Quality Management: Three Steeps to Continous Improvement. Massachuset: Addison-Weley Publishing Company.

Tjiptono, F. \& Diana, D. 2000. Total Quality Management. Yogyakarta: Andi Offset.

Varnavas, A.P. \& Soteriou, A.C. 2002. "TowardsCustomer-Driven Management in Hospitality Education: A Case Study of the Higher Hotel Institute. International Journal of Educational Management, Volume: 16 Issue: 2. 